\title{
PERBANDINGAN KINERJA KEUANGAN PERUSAHAAN FARMASI MILIK BUMN DAN SWASTA DI BEI PERIODE 2016- 2018
}

\author{
Lia Candrayani \\ IAIN Kudus \\ email.lia.candrayani.20@gmail.com \\ Ziana Fitri \\ IAIN Kudus \\ email.fitriziana@gmail.com \\ Kharis Fadlullah Hana \\ IAIN Kudus \\ email.kharis@iainkudus.ac.id
}

\begin{abstract}
The purpose of this study was to determine the comparison of the financial performance of state-owned pharmaceutical companies with private-owned pharmaceutical companies and find out what factors affect differences in company performance based on analysis of profitability, market value rations and EVA. This study using a quantitative approach using a comparative descriptive method that took a sample of 4 pharmaceutical companies listed on the Stock Excahange. The data analysis technique uses a different independent sample T-test by comparing financial data from state-owned and private pharmaceutical companies in the 2016-2018 period. The results of the study show that return on equity (ROE) analysis of state-owned pharmacentical companies is not safe because there are significant differences in the precentage above 15\% and private pharmaceutical above 15\%. The earning per share (EPS) analysis results of state-owned companies reached 0,35 and private pharmaceutical companies reached 50,71. As well as economic value added (EVA) analysis produces data there are differences in financial performace where the state-owned pharmaceutical companies have increased and privat pharmaceutical companies have decreased.
\end{abstract}

Keywords: Financial performance, ROE, EPS, EVA 


\section{Pendahuluan}

Globalisasi perekonomian akan membuka peluang pasar baru terhadap produk dalam negeri namun globalisasi perekonomian ini akan berdampak dikegiatan ekonomi serta perdagangan dibeberapa negara dan keberadannya menjadi dilema, peluang pasar mampu membuka produk-produk dalam negeri berupa pasar internasional dan disisi lain juga membuka peluang produkproduk luar negeri seperti pasar domestik. Perkembangan ekonomi memiliki efek positif serta efek negatif bagi setiap negara, salah satunya efek positif yang ditimbulkan dari globalisasi perekonomian seperti semakin mudah memperoleh modal dari negara lain namun jika pemerintahannya tidak dapat megelola dana tersebut akan mengakibatkan krisis ekonomi karena melemahnya nilai mata uang negara. Indonesia merupakan negara yang merasakan dampak negatif dari globalisasi ekonomi seperti ketergantungan terhadap impor pada perusahaan farmasi yang hamper bahan bakunya 95\% diimpor dari Cina dan India (Mardiyani 2017).

Indonesia menjadi pasar industri farmasi karena jumlah penduduk yang tinggi serta akses terhadap kesehatan yang meningkat hal ini karena adanya implementasi BPJS kesehatan dan semakin meningkatnya kesadaran masyarakat terhadap kesahatan (Nurhidayah, Ronny Malavia Mardani n.d.). Produk industri farmasi obat-obatan harus memenuhi syarat diantaranya safety, efficacy, dan quality. Pada industri farmasi diharapkan mampu mengoreksi diri pada penerapan teknologi modern berstandar nasional. Realitanya perusahaan farmasi di Indonesia dikuasai BUMN hal ini dapat dilihat dari ikhtisar beban perusahaan. Apabila dilihat dari pendapatan perusahaan farmasi para investor lebih memilih menanamkan dananya di perusahaan farmasi swarta, hal ini disebabkan perusahaan farmasi milik BUMN fokus dalam memproduksi obat generik guna untuk meningkatkan pendapatannya sedangkan untuk perusahaan farmasi milik swasta lebih fokus dalam memproduksi suplemen dan nutrisi. Perusahaan farmasi swasta memiliki layanan yang lebih unggul serta dapat menghasilkan bahan-bahan farmasi. Diharapkan para investor lebih teliti dalam membaca laporan keuangan perusahaan farmasi BUMN maupun perusahaan farmasi swasta guna sebagai gambaran untuk investor dalam merencanakan investasinya (Mardiyani 2017). Untuk mengetahui kondisi keuangan perusahaan farmasi BUMN dan perusahaan farmasi swasta dapat dilihat melalui laporan laba rugi yang dapat memberikan gambaran mengenai perkembangan perusahaan selama periode tertentu (Doerachman, Tommy, and Rate 2016).

Berbagai penelitian telah dilakukan mengenai analisis perbandingan kinerja keuangan di perusahaan farmasi milik BUMN dan swasta, para peneliti mempunyai anggapan masing-masing yang berkaitan dengan penelitian tersebut. Penelitian yang dilakukan oleh Mardiyani (2017) memaparkan hasilnya bahwa dari perbandingan kinerja keuangan milik perusahaan farmasi BUMN dan swasta dalam analisis ROE terdapat perbedaan yang signifikan, hal ini karena ROE pada perusahaan farmasi swasta berada diposisi aman yakni diatas persentase $15 \%$ sedangkan untuk perusahaan farmasi milik BUMN 
berada diposisi tidak aman. Jika dilihat dari analisis EPS kedua perusahaan tersebut menghasilkan perbedaan yang signifikan hal ini karena saham milik perusahaan swasta rata-rata jauh lebih tinggi dibandingkan perusahaan farmasi milik BUMN. kemudian untuk anaisis EVA pada kedua perusahaan ini menghasilkan tidak adanya perbedaan yang signifikan dikarenakan hasil nilai EVA dari perusahaan farmasi BUMN dan swasta sama-sama memiliki nilai EVA yang menunjukan negatif (Mardiyani 2017). Selanjutnya penelitian yang dilakukan oleh Nurhidayah, Ronny Malavia Mardani, dan M Agus menemukan bahwa dalam rasio likuiditas pada perusahaan farmasi BUMN lebih rendah dari pada perusahaan farmasi swasta. Untuk rasio aktivitas pada perusahaan farmasi BUMN lebih tinggi dibandingkan perusahaan farmasi swasta. Serta untuk rasio solvabilitas pada perusahaan Farmasi BUMN lebih tinggi dibandingkan dengan perusahaan farmasi swasta, hal ini dapat diartikan bahwa nilai rasio solvabilitas pada perusahaan farmasi BUMN lebih buruk, jika nilai rasio solvabilitas tinggi maka utang yang dimiliki sebuah perusahaan tersebut juga tinggi. Dalam rasio profitabilitas pada perusahaan farmasi swasta lebih unggul dibandingkan dengan perusahaan farmasi milik BUMN (Nurhidayah, Ronny Malavia Mardani n.d.). Selanjutnya penelitian yang dilakukan oleh Gladys Theresia Pricilia Sampul dalam penelitiannya menghasilkan bahwa tidak ada perbedaan antara perusahaan farmasi milik BUMN dan perusahan farmasi milik swasta. Hal ini disebabkan karena setiap nilai variable menghasilkan nilai provitabilitas diatas 0.05. Perusahaan farmasi swasta dituntut mengembangkan serta mempertahankan yang telah dicapai sedangkan untuk perusahaan farmasi BUMN dapat memberikan kebebasan manajemen dalam mengelola perusahaan supaya perusahaan dapat mengembangkan produknya (Sampul et al. 2013).

Berdasarkan pemaparan diatas, penulis bermaksud untuk melakukan penelitian pada perusahaan farmasi milik BUMN dan perusahaan farmasi milik swasta, dalam penelitian ini untuk mengetahui kinerja keuangan pada perusahaan farmasi milik BUMN dan perusahaan farmasi milik swasta serta untuk mengetahui faktor-faktor yang dapat mempengaruhi dalam kinerja keuangan perusahaan yang berdasarkan analisis profitabilitas, rasio nilai pasar, dan EVA.

\section{Tinjauan Pustaka}

Performance adalah gambaran dalam pencapaian suatu program guna untuk mewujudkan visi dan misi dari suatu organisasi yang melalui perencanaan (M. Abdullah 2014). Prestasi kinerja biasanya dikaitkan dengan hasil dari pekerjaan seseorang yang akan dipandang (Galib, Mukhtar 2018). Teori kinerja perusahaan menurut Moerdiyanto merupakan sebuah bisnis yang dilakukan dalam pengorbanan ke berbagai mmacm sumber daya manusia maupun dalam bidang keuangan (Moerdiyanto 2010). Gencarnya perusahaan dalam memperoleh profit yang akan dihasilkan dan dipengaruhi berdasarkan proses perkembangan laba perusahaan tersebut. 
Laporan keuangan dan data non keuangan yang dimiliki perusahaan digunakan sebagai alat ukur keberhasilan suatu perusahaan. Kinerja perusahaan memiliki informasi untuk mengukur daya tampung arus kas dari sumber dana yang ada di perusahaan (Sampul et al. 2013).

Pasar modal merupakan indikator laju perkembangan perekonomian suatu negara guna membangun kemajuan ekonomi pemerintah yang bersangkutan. Perusahaan industri farmasi di Indonesia mengalami perkembangan, dalam perkembangan tersebut dapat menumbuhkan daya saing yang secara sehat, luas dan kuat. Perkembangan investasi di pasar modal biasanya diamati melalui Bursa Efek Indonesia (BEI) (Doerachman et al. 2016).

Menteri Keuangan Republik Indonesia No. 740/KMK.00/1989 memutuskan kinerja keuangan adalah perusahaan yang mendapatkan prestasi pada periode tertentu mengenai tingkat kesehatan perusahaan dan dasar penilaian menangani kondisi keuangan yang dilakukan berdasarkan analisis rasio(Ratih F D Simbolon, Moch. Dzulkiron 2014).

Menurut Munawir menjelaskan bahwa kinerja keuangan adalah suatu perusahaan yang memperoleh prestasi kerja dalam periode tertentu yang tertuang pada laporan keuangan yang bersangkutan (Nurmila Dewi 2016). Pada umumnya kinerja keuangan dilakukan untuk pengambilan keputusan guna mencapai hasil yang maksimal, kompetitif dan profesional di suatu perusahaan. Salah satu perusahaan dapat dikatakan baik maupun buruk dalam kinerja keuangan dapat dilihat dari output dan perusahaan yang sudah go public di kalangan eksternal masyarakat, terutama pada penilaian kinerja perusahaan yang dinilai mengimplementasikan program pemulihan usaha industri farmasi pada setiap tahunnya (Mardiyani 2017).

Menurut Gibson ada beberapa faktor yang mempengaruhi kinerja keuangan yakni sebagai berikut:

1. Variabel individual faktor ini berupa tindakan atau ketrampilan, fikiran, tenaga, masalah, upah, dan penduduk.

2. Variabel organisasional faktor ini dapat meliputi sumber daya, kepemimpinan, imbalan, struktur desain pekerjaan.

3. Variabel psikologis faktor ini dapat berupa persepsi, belajar, kebribadian motivasi serta sikap (Saragih 2017)

Laporan keuangan berfungsi untuk mengetahui kondisi kesehatan dari suatu perusahaan. Dalam sebuah laporan keuangan meliputi neraca, perhitungan laba rugi, ikhtisar laba ditahan serta laporan posisi keuangan. Menurut Standar Akuntansi Keuangan (SAK) menerangkan bahwa laporan keuangan merupakan proses pelaporan keuangan yang lengkap, yang mana laporan keuangan tersebut meliputi neraca, laporan laba rugi, laporan perubahan posisi keuangan yang dapat disajikan seperti laporan arus kas, laporan arus dana (Doerachman et al. 2016).

Secara umum laporan keuangan dapat memberikan gambaran mengenai keuangan dari suatu perusahaan, laporan keuangan dapat disusun secara mendadak. Dalam laporan keuangan terdapat 2 sifat yakni laporan keuangan 
bersifat historis merupakan laporan keuangan yang dibuat dan disusun dari data masa lampau, dan laporan keuangan bersifat menyeluruh merupakan laporan keuangan yang dibuat selengkap mungkin dan menganut standar yang telah ditentukan (Kasmir 2009).

Kinerja keuangan dianalisis dan diukur perusahaan industri untuk memperoleh laba. Menurut kasmir rasio keuangan adalah teknik analisis membandingkan angka di laporan keuangan dengan cara membagi satu angka dengan angka yang lain. (Mardiyani 2017).

Seorang analisis perbandingan rasio laporan keuangan dituntut mempelajari mengenai perubahan yang terjadi dan menentukan apakah terjadi peningkatan atau penurunan dalam kondisi keuangan per tahun pada kurun waktu tertentu (Ratu 2016). Menurut Prastowo rasio keuangan terdiri dari rasio likuiditas, rasio aktivitas, rasio solvabilitas, rasio profitabilitas dan rasio pasar (Iwin Arnova 2013).

Rasio profitabilitas menurut Kasmir merupakan rasio yang digunakan untuk menilai kemampuan suatu perusahaan dalam memperoleh laba. Rasio profitabilitas berfungsi untuk memberikan gambaran mengenai tingkat efektivitas manajemen perusahaan yang ditunjukan oleh laba yang diperoleh dari penjualan dan pendapatan investasi. Ada beberapa jenis rasio profitabilitas yakni sebagai berikut:

1. Profit Margin.

2. Return On Investment.

3. Return On Equity.

4. Laba per lembar saham.

5. Rasio pertumbuhan. (Kasmir 2009)

Jenis-jenis rasio profitabilitas terdapat return on equity (ROE), menurut Hanafi dan Halim dalam jurnal penelitian Enniyatul Mizan menyatakan bahwa return on equity (ROE) merupakan rasio yang mengukur kemampuan perusahaan untuk mendapatkan keuntungan berdasarkan modal saham tertentu (Enniyatul Mizan 2018).

Rasio nilai pasar dapat memberikan pemahaman bagi pihak manajemen perusahaan yang mengenai bagaimana pandangan seorang investor terhadap resiko dan prospek yang akan terjadi pada waktu yang akan datang (Ratu 2016).

Dalam penilaian rasio nilai pasar terdapat Earning Per Share (EPS) atau pendapatan per lembar saham, menurut Fahmi EPS merupakan pemberian laba dari suatu perusahaan yang diberikan kepada para pemegang saham dari setiap lembar yang dimilikinya. Semakin tinggi nilai EPS suatu perusahaan maka akan menarik investor untuk berinvestasi (Rahma Febriyanti 2014).

Menurut Rudianto economic value added (EVA) adalah kinerja keuangan perusahaan yang diukur dalam kehidupan sehari-hari berupa pengurangan biaya dan kenaikan pendapatan EVA dalam satu periode yang relevan (Yoga Prasetyo, Mulatsih., MM 2019). Economic value added (EVA) dapat digunakan untuk memilih dan mengendalikan operasi investasi keuangan perusahaan yang dinilai paling menjanjikan (Dorotea Noesman Riberu 2017). 


\section{Metode Penelitian}

1. Jenis Penelitian

Penelitian ini menggunakan pendekatan kuantitatif dengan metode deskriptif komparatif yakni penelitian yang sifatnya membandingkan sehingga diperoleh gambaran mengenai rasio provitabilas, nilai pasar dan EVA. Dalam analisisnya menggunakan uji independen sample T-Test dengan membandingkan data keuangan dari perusahaan farmasi BUMN dan perusahaan farmasi swasta periode 2016-2018.

\section{Jenis Data}

Data penelitian menggunakan data sekunder diambil secara time series yang diakses melalui (www.idx.co.id) dan situs resmi perusahaan farmasi BUMN dan perusahaan farmasi swasta. Dalam penelitian ini menggunakan data dari laporan keuangan industri perusahaan farmasi BUMN dan perusahaan farmasi swasta yang terdaftar di BEI.

3. Teknik Pengumpulan Data

Pengumpulan data merupakan teknik yang digunakan untuk memperoleh data yang akan digunakan (Ahmad Tanzeh 2009). Teknik dalam pengumpulan data dilakukan secara dokumenter yakni data yang dipublikasikan perusahaan farmasi BUMN dan perusahaan farmasi swasta pada periode 2016-2018.

4. Populasi dan sampel

Populasi yang digunakan dalam penelitian ini yakni perusahaan farmasi BUMN dan perusahaan farmasi swasta yang terdaftar di BEI pada periode 2016-2018. Sampel dalam penelitian ini menggunakan purposive judgement sampling dengan meneliti 4 buah perusahaan farmasi yang terdiri dari 2 perusahaan farmasi BUMN yakni INAF dan KAEF serta 2 perusahaan farmasi swasta yakni DVLA dan KAEF.

\section{Hasil dan Pembahasan}

Berikut ini data yang diperoleh dari laporan keuangan perusahaan farmasi BUMN dan perusahaan farmasi swasta pada taun 2016-2018 dengan mengambil 4 sampel perusahaan farmasi, data diakses melalui www.idx.co.id.

Tabel 1:

Hasil perhitungan ROE, EPS, EVA

\begin{tabular}{|c|c|c|c|c|}
\hline $\begin{array}{c}\text { Kode } \\
\text { Saham }\end{array}$ & Tahun & ROE (\%) & EPS (Rp) & EVA (jt) \\
\hline INAF & 2016 & $-3,02$ & $-5,60$ & 12.410 \\
\hline & 2017 & $-8,79$ & $-14,93$ & -22.388 \\
\hline & 2018 & $-6,59$ & $-10,56$ & 5.615 \\
\hline KAEF & 2016 & 11,96 & 48,9 & 137.308 \\
\hline & 2017 & 12,89 & 59,72 & 181.031 \\
\hline & 2018 & 11,97 & 72,34 & 284.310 \\
\hline
\end{tabular}




\begin{tabular}{|c|c|c|c|c|}
\hline $\begin{array}{c}\text { Kode } \\
\text { Saham }\end{array}$ & Tahun & ROE (\%) & EPS (Rp) & EVA (jt) \\
\hline DVLA & 2016 & 14,09 & 13,63 & 24 \\
\hline & 2017 & 14,53 & 14,54 & 35 \\
\hline & 2018 & 16,72 & 17,98 & 43 \\
\hline KLBF & 2016 & 18,86 & 50,15 & 341.418. \\
\hline & 2017 & 17,66 & 52,34 & 307.455 \\
\hline & 2018 & 16,33 & 53,27 & 297.049 \\
\hline
\end{tabular}

Sumber: Pengolahan Data (2020)

Perbandingan kinerja keuangan perusahaan farmasi BUMN dan perusahaan farmasi swasta periode 2016-2018 berdasarkan ROE

Tabel 2:

Group Statistics

\begin{tabular}{|c|c|c|r|r|r|}
\hline & $\begin{array}{c}\text { Perusaha } \\
\text { an } \\
\text { Farmasi }\end{array}$ & $\mathrm{N}$ & Mean & Std. Deviation & Std. Error Mean \\
\hline $\mathrm{R}$ & BUMN & 3 & 3,0700 & 1,25395 &, 72397 \\
$\mathrm{O}$ & BUMS & 3 & 16,3700 &, 23516 &, 13577 \\
$\mathrm{E}$ & & & & & \\
\hline
\end{tabular}

Sumber: Pengolahan Data (2020)

Berdasarkan tabel output 2 "Group Statistics" diatas menjelaskan bahwa perusahaan farmasi BUMN memperoleh nilai mean 16,3700. Pada perusahaan farmasi BUMN yang berdasarkan standar deviasi dan standar error mean lebih tinggi daripada perusahaan farmasi milik swasta. Jadi disimpulan bahwa terdapat perbedaan pada kinerja keuangan perusahaan farmasi milik BUMN dengan perusahaan farmasi milik swasta.

Tabel 3:

Uji Homogenity

\begin{tabular}{|ll|c|c|}
\hline \multirow{2}{*}{} & \multicolumn{2}{|c|}{ Levene's Test for Equality of Variances } \\
\cline { 3 - 4 } & F & Sig. \\
\hline RO & $\begin{array}{l}\text { Equal variances } \\
\text { E }\end{array}$ & 6,249 &, 067 \\
& $\begin{array}{l}\text { Equal variances not } \\
\text { assumed }\end{array}$ & & \\
\hline
\end{tabular}

Sumber: Pengolahan Data (2020) 
Dari tabel output 3 dapat diketahui jika nilai Sig sebesar 0,067>0,05 sehingga dinyatakan lolos uji homogenity serta data dari kedua populasi tersebut sama (homogen).

Tabel 4:

Independent Samples T-Test

\begin{tabular}{|c|c|c|c|c|c|c|c|}
\hline & & & & -test for Eq & lity of Means & & \\
\hline & & & Sig. (2- & $\mathrm{Me}$ & Std. Error & $\begin{array}{r}95 \% \text { Co } \\
\text { Interva } \\
\text { Diffe }\end{array}$ & $\begin{array}{l}\text { fidence } \\
\text { of the } \\
\text { ence }\end{array}$ \\
\hline & $\mathrm{T}$ & Df & tailed) & Difference & Difference & Lower & Upper \\
\hline $\mathrm{R}$ & - & 4 & 000 & $-13,30000$ & ,73659 & $-15,34511$ & \\
\hline C & 18,0 & & & & & & 11,25489 \\
\hline $\mathrm{E}$ & 56 & & & & & & \\
\hline & - & 2,14 & ,002 & $-13,30000$ & ,73659 & $-16,27805$ & 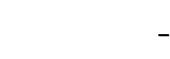 \\
\hline & $\begin{array}{r}18,0 \\
56\end{array}$ & 1 & & & & & 10,32195 \\
\hline
\end{tabular}

Sumber: Pengolahan Data (2020)

Berdasarkan tabel output 4 menghasilkan nilai Sig sebesar $0.000<0,05$ jadi dapat disimpulkan bahwa nilai $\mathrm{HO}$ ditolak dan $\mathrm{Ha}$ diterima, sehingga terdapat perbedaan terhadap kinerja keuangan perusahaan farmasi BUMN dan perusahaan farmasi swasta. Diketahui nilai mean difference sebesar -13.30000 dalam nilai ini menunjukan selisih 3,0700-16,3700 $=-13,30000$ dan selisih perbedaan tersebut $-15,34511$ sampai -11,25489. Untuk mengetahui perbedaan nilai ROE pada perusahaan farmasi BUMN dan perusahaan farmasi swasta dapat dilihat pada analisis fundamental dibawah ini.

\section{Tabel 5:}

Perbandingan rata-rata ROE pada perusahaan farmasi BUMN dan perusahaan farmasi swasta (dalam jutaan Rp)

\begin{tabular}{|l|r|r|r|r|}
\hline & \multicolumn{1}{|c|}{2016} & \multicolumn{1}{c|}{2017} & \multicolumn{1}{c|}{2018} & \multicolumn{1}{c|}{ Rata-rata } \\
\hline $\begin{array}{l}\text { Farmasi } \\
\text { BUMN }\end{array}$ & & & & \\
\hline $\begin{array}{l}\text { Net } \\
\text { Income }\end{array}$ & $127.115,50$ & $142.711,50$ & $184.528,50$ & $151.451,8$ \\
\hline Equity & 1.423 .582 & $1.549 .465,50$ & $1.926 .553,50$ & $1.633 .200,3$ \\
\hline ROE & $\mathbf{8 , 9 3}$ & $\mathbf{9 , 2 1}$ & $\mathbf{9 , 5 8}$ & $\mathbf{9 , 2 7}$ \\
\hline $\begin{array}{l}\text { Farmasi } \\
\text { Swasta }\end{array}$ & & & & \\
\hline $\begin{array}{l}\text { Net } \\
\text { Income }\end{array}$ & $1.251 .484,20$ & $1.307 .750,10$ & $1.329 .957,00$ & $1.296 .397,1$ \\
\hline
\end{tabular}




\begin{tabular}{|l|r|r|r|r|}
\hline Equity & $6.771 .713,30$ & $7.505 .166,00$ & $8.247 .428,40$ & $7.508 .102,6$ \\
\hline ROE & $\mathbf{1 8 , 4 0}$ & $\mathbf{1 7 , 4 0}$ & $\mathbf{1 6 , 1 0}$ & $\mathbf{1 7 , 2 7}$ \\
\hline
\end{tabular}

Berdasarkan perhitungan tabel diatas jika dilihat dari analisis fundamental ROE menjelaskan bahwa pada perusahaan farmasi swasta berada diposisi aman karena nilainya diatas 15\%. Jika ditelusuri lebih lanjut pada kedua perusahaan farmasi tersebut untuk net income dan nilai ekuitas menunjukan nilai yang berbeda. Dapat dilihat bahwa nilai ekuitas pada perusahaan farmasi sebesar 1.633.2003,3 juta sedangkan pada perusahaan farmasi swasta mencapai 7.508.102,6 juta hal ini yang mengakibatkan net income perusahaan farmasi BUMN mencapai 151.451,8 juta, sementara untuk perusahaan farmasi swasta mencapai 1.296.397,1 juta. Apabila dilihat dari struktur modal maka perusahaan farmasi swasta lebih unggul daripada perusahaan farmasi BUMN.

Agar dapat meningkatkan nilai ROE nya perusahaan farmasi dapat mencari struktural modal dengan menambah sumber dana agar net income dari perusahaan dapat meningkat.

Tabel 6.

Group Statistics

Perbandingan kinerja keuangan berdasarkan perhitungan EPS periode 2016-

2018

\begin{tabular}{|ll|c|c|c|c|}
\hline \multicolumn{2}{|c|}{$\begin{array}{c}\text { Perusahaan } \\
\text { Farmasi }\end{array}$} & & & & \\
\hline E & BUMN & 3 & 24,9800 & 5,13193 & 2,96292 \\
P & BUMS & 3 & 39,6300 & 12,11421 & 6,99414 \\
S & & & & & \\
\hline
\end{tabular}

Sumber: Pengolahan Data (2020)

Berdasarkan tabel output 6 "Group Statistics" diatas menjelaskan bahwa perusahaan farmasi BUMN memperoleh nilai mean 24,9800, sementara untuk perusahaan farmasi swasta adalah sebesar 39,6300. Jadi disimpulan bahwa terdapat perbedaan pada rata-rata tada hasil EPS kinerja keuangan perusahaan farmasi milik BUMN dengan perusahaan farmasi milik swasta.

Tabel 7:

Uji Homogenity

\begin{tabular}{|c|c|c|}
\hline & $\begin{array}{ll}\text { Levene's } & \mathrm{T} \\
\text { Variances } & \\
\end{array}$ & quality of \\
\hline & $\mathrm{F}$ & Sig. \\
\hline $\begin{array}{ll}\text { EPS } & \text { Equal variances assumed } \\
& \text { Equal variances not assumed } \\
\end{array}$ & 4,345 & , 105 \\
\hline
\end{tabular}


Dari tabel output 7 dapat diketahui jika nilai Sig sebesar 0,105>0,05 sehingga dinyatakan lolos uji homogenity serta data dari kedua populasi tersebut sama (homogen).

Tabel 8:

Independent Samples Test

\begin{tabular}{|c|c|c|c|c|c|c|c|}
\hline & \multicolumn{7}{|c|}{ t-test for Equality of Means } \\
\hline & \multirow[b]{2}{*}{$\mathrm{T}$} & \multirow[b]{2}{*}{$\mathrm{df}$} & \multirow[b]{2}{*}{$\begin{array}{l}\text { Sig. } \\
(2- \\
\text { tailed }) \\
\end{array}$} & \multirow[b]{2}{*}{$\begin{array}{c}\text { Mean } \\
\text { Difference }\end{array}$} & \multirow[b]{2}{*}{$\begin{array}{l}\text { Std. Error } \\
\text { Difference }\end{array}$} & \multicolumn{2}{|c|}{$\begin{array}{c}95 \% \text { Confidence } \\
\text { Interval of the } \\
\text { Difference }\end{array}$} \\
\hline & & & & & & Lower & Upper \\
\hline EPS & $\begin{array}{c}- \\
1,929\end{array}$ & 4 & ,126 & $-14,65000$ & 7,59585 & $\begin{array}{c}- \\
35,73946\end{array}$ & 6,43946 \\
\hline & $\begin{array}{c}- \\
1,929\end{array}$ & 2,695 & 160 & $-14,65000$ & 7,59585 & $\begin{array}{c}- \\
40,44445\end{array}$ & 11,14445 \\
\hline
\end{tabular}

Sumber: Pengolahan Data (2020)

Berdasarkan tabel output 8 menghasilkan nilai Sig sebesar 0.126>0,05 jadi dapat disimpulkan bahwa nilai H0 diterima dan Ha ditolak. Jadi tidak terdapat perbedaan terhadap kinerja keuangan perusahaan farmasi BUMN dan perusahaan farmasi swasta. Diketahui nilai mean difference sebesar -14,65000 dalam nilai ini menunjukan selisih 24,9800-39,6300 $=-14,65000$ dan selisih perbedaan tersebut $-35,73946$ sampai 6,43946. Untuk mengetahui perbedaan nilai EPS pada perusahaan farmasi BUMN dan perusahaan farmasi swasta dapat dilihat pada analisis fundamental dibawah ini.

Tabel 9:

Perbandingan rata-rata EPS perusahaan farmasi BUMN dan perusahaan farmasi swasta periode 2016-2018 (dalam jutaan Rp)

\begin{tabular}{|c|c|c|c|c|c|c|c|c|}
\hline \multirow{2}{*}{$\begin{array}{l}\text { Farmasi } \\
\text { BUMN }\end{array}$} & \multicolumn{2}{|c|}{2016} & \multicolumn{2}{|c|}{2017} & \multicolumn{2}{|c|}{2018} & \multicolumn{2}{|c|}{ Rata-rata } \\
\hline & & & & & & & & \\
\hline $\begin{array}{l}\text { Laba } \\
\text { bersih }\end{array}$ & $\mathrm{Rp}$ & 127.115 & $\mathrm{Rp}$ & 142.712 & $\mathrm{Rp}$ & 184.528 & $\mathrm{Rp}$ & 151.452 \\
\hline $\begin{array}{l}\text { Saham } \\
\text { yang } \\
\text { beredar }\end{array}$ & $\mathrm{Rp}$ & 432.663 & $\mathrm{Rp}$ & 432.663 & $\mathrm{Rp}$ & 432.665 & $\mathrm{Rp}$ & 432.663 \\
\hline EPS & & 0,29 & & 0,33 & & 0,43 & & 0,35 \\
\hline
\end{tabular}




\begin{tabular}{|c|c|c|c|c|}
\hline $\begin{array}{l}\text { Farmasi } \\
\text { Swasta }\end{array}$ & & & & \\
\hline $\begin{array}{l}\text { Laba } \\
\text { bersih }\end{array}$ & Rp 1.248.731 & Rp 1.226.707 & Rp 1.175.518 & Rp 1.216.985 \\
\hline $\begin{array}{l}\text { Saham } \\
\text { yang } \\
\text { beredar }\end{array}$ & 23.998 & 23.998 & 23.998 & 23.998 \\
\hline EPS & 52,04 & 51,12 & 48,99 & 50,71 \\
\hline
\end{tabular}

Berdasarkan perhitungan tabel diatas jika dilihat dari analisis fundamental EPS menjelaskan bahwa terdapat perbedaan. Untuk perusahaan farmasi BUMN hanya mencapai 0,35 saja, sedangkan untuk perusahaan farmasi swasta dapat mencapai 50,71. Jika ditelusuri untuk net income dan jumlah saham yang beredar berbeda, untuk net income pada perusahaa farmasi BUMN mencapai 151.452 juta sedangkan untuk perusahaan farmasi swasta sebesar 1.216.985 juta. Jumlah saham yang beredar pada perusahaan farmasi milik BUMN sebesar 432.665 sedangkan untuk perusahaan farmasi swasta sebesar 23.998.

Berdasarkan perbandingan diatas dapat disimpulkan bahwa laba per saham dari perusahaan farmasi BUMN dan swasta tiap tahunnya tetap. Apabila dilihat dari laba per saham maka yang diminati investor yakni perusahaan BUMN serta laba yang diperoleh juga mengalami peningkatan setiap tahunnya. Sementara perusahaan farmasi swasta untuk untuk tingkat laba yang diperoleh tidak signifikan.

Perusahaan farmasi BUMN dapat menarik investor untuk menginvestasikan dananya guna untuk meningkatkan nilai EPS nya, hal ini dapat mengingat bahwa penjualan obat denerik tergolong cukup tinggi khususnya di Indonesia.

Tabel 10:

Group Statistics

Perbandingan kinerja keuangan farmasi BUMN dan perusahaan farmasi swasta periode 2016-2018 berdasarkan EVA

\begin{tabular}{|cc|c|c|c|c|}
\hline \multicolumn{2}{|c|}{$\begin{array}{c}\text { Perusahaan } \\
\text { Farmasi }\end{array}$} & $\mathrm{N}$ & Mean & Std. Deviation & Std. Error Mean \\
\hline $\mathrm{E}$ & BUMN & 3 & 99714,00 & 39249,376 & 22660,638 \\
$\mathrm{~V}$ & BUMS & 3 & 157670,67 & 11597,017 & 6695,541 \\
$\mathrm{~A}$ & & & & \\
\hline
\end{tabular}

Sumber: Pengolahan Data (2020)

Berdasarkan tabel output 10 "Group Statistics" diatas menjelaskan bahwa perusahaan farmasi BUMN memperoleh nilai mean mean 99714,00 lebih kecil daripada perusahaan farmasi millik swasta dengan nilai mean 
157670,67. Sedangkan dengan pada standar deviasi dan standar eror mean antar perusahaan farmasi BUMN lebih besar dari perusahaan farmasi milik swasta. Sehingga dapat disimpulkan hasil dari analisis statistik deskriptif ada perbedaan terhadap kinerja keuangan perusahaan farmasi milik BUMN dan perusahaan farmasi milik swasta.

Tabel 11:

Uji Homogenity

\begin{tabular}{|c|c|c|c|}
\hline & \multicolumn{2}{|c|}{ Levene's Test for Equality of Variances } \\
\hline & & $\mathrm{F}$ & Sig. \\
\hline$\overline{\mathrm{EVA}}$ & $\begin{array}{l}\text { Equal variances assumed } \\
\text { Equal variances not } \\
\text { assumed }\end{array}$ & 7,033 & ,057 \\
\hline
\end{tabular}

Sumber: Pengolahan Data (2020)

Dari tabel output 11 dapat diketahui jika nilai Sig sebesar 0,57>0,05 sehingga dapat maka dinyatakan lolos uji homogenity serta data dari kedua populasi tersebut sama (homogen).

Tabel 12:

Independent Samples Test

\begin{tabular}{|c|c|c|c|c|c|c|c|}
\hline & \multicolumn{7}{|c|}{ t-test for Equality of Means } \\
\hline & \multirow[b]{2}{*}{$\mathrm{T}$} & \multirow[b]{2}{*}{ Df } & \multirow{2}{*}{$\begin{array}{l}\text { Sig. } \\
(2- \\
\text { tailed } \\
\text { ) }\end{array}$} & \multirow{2}{*}{$\begin{array}{c}\text { Mean } \\
\text { Differenc } \\
\mathrm{e}\end{array}$} & \multirow{2}{*}{$\begin{array}{c}\text { Std. Error } \\
\text { Differenc } \\
\text { e }\end{array}$} & \multicolumn{2}{|c|}{$\begin{array}{l}95 \% \text { Confidence } \\
\text { Interval of the } \\
\text { Difference }\end{array}$} \\
\hline & & & & & & Lower & Upper \\
\hline \multirow{4}{*}{$\begin{array}{l}\mathrm{EV} \\
\mathrm{A}\end{array}$} & - & 4 &, 070 & - & 23629,108 & 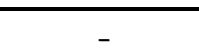 & 7648,256 \\
\hline & 2,45 & & & 57956,667 & & 123561,58 & \\
\hline & - & 2,34 & 115 & - & 23629,108 & - & 30594,72 \\
\hline & $\begin{array}{c}2,45 \\
3\end{array}$ & 7 & & 57956,667 & & $\begin{array}{c}146508,05 \\
6\end{array}$ & 3 \\
\hline
\end{tabular}

Sumber: Pengolahan Data (2020)

Berdasarkan tabel output 12 menghasilkan nilai Sig sebesar 0,070>0,05 jadi dapat disimpulkan bahwa nilai $\mathrm{HO}$ diterima dan $\mathrm{Ha}$ ditolak. Jadi tidak terdapat perbedaan terhadap kinerja keuangan perusahaan farmasi BUMN dan perusahaan farmasi swasta. Diketahui nilai mean difference sebesar -57956,667 dalam nilai ini menunjukan selisih 99714,00-157670,67 $=-57956,667$ dan selisih perbedaan tersebut adalah $-123561,589$ sampai 7648,256. Untuk 
mengetahui perbedaan nilai EVA pada perusahaan farmasi BUMN dan perusahaan farmasi swasta dapat dilihat pada analisis fundamental dibawah ini.

Tabel 13:

Perbandingan rata-rata EVA perusahaan farmasi BUMN dan perusahaan farmasi swasta periode 2016-2018 (dalam milyaran Rp)

\begin{tabular}{|l|r|r|r|r|}
\hline & \multicolumn{1}{|c|}{2016} & \multicolumn{1}{c|}{2017} & \multicolumn{1}{c|}{2018} & \multicolumn{1}{c|}{ Rata-rata } \\
\hline Farmasi BUMN & & & & 228.947 \\
\hline NOPAT & 181.640 & 201.423 & 303.777 & 0,041 \\
\hline WAAC & 0,048 & 0,038 & 0,037 & 2.376 .253 \\
\hline IC & 1.796 .528 & 2.181 .613 & 3.150 .617 & $\mathbf{1 3 1 . 5 2 0}$ \\
\hline EVA & $\mathbf{9 5 . 4 0 7}$ & $\mathbf{1 1 8 . 5 2 2}$ & $\mathbf{1 8 7 . 2 0 4}$ & \\
\hline Farmasi Swasta & & & & \\
\hline NOPAT & 1.175 .513 & 1.226 .704 & 1.248 .728 & 1.216 .982 \\
\hline WAAC & 0,129 & 0,125 & 0,129 & 0,128 \\
\hline IC & 6.455 .002 & 7.195 .051 & 7.930 .652 & 7.193 .568 \\
\hline EVA & & & & $\mathbf{2 9 8 . 6 0 3}$ \\
\hline
\end{tabular}

Berdasarkan perbandingan dari tabel EVA diatas untuk nilai NOPAT pada perusahaan farmasi BUMN dan perusahaan farmasi swasta mengalami peningkatan akan tetapi nilai EVA pada perusahaan farmasi swasta mengalami penurunan setiap tahunnya. Dari perbedaaan kedua perusahaan farmasi tersebut dapat disimpulkan bahwa terdapat perbedaan dalam kinerja keuangan farmasi BUMN dan perusahaan farmasi swasta. Untuk nilai EVA pada perrusahaan BUMN selama tiga tahun mengalami peningkatan yang lumayan signifikan, sedangkan nilai EVA untuk perusahaan farmasi swasta selama tiga tahun terakhir kinerja keuangannya mengalami penurunan yang mana dapat dilihat pada tabel diatas bahwa pada tahun 2017 ke 2018 kinerja keuangannya mengalami penurunan yang signifikan. Yang dapat dilakukan untuk kedua perusahaan farmasi tersebut dengan meningkatkan profit tanpa harus menambah modal atau dapat mengurangi modal hal ini dilakukan guna dalam pengembalian dana yang diinvestasikan tidak bertambah.

\section{Kesimpulan}

Berdasarkan hasil pembahasan dan pengujian data melalui pengolahan uji statistik terhadap kinerja keuangan perusahaan farmasi milik BUMN dan perusahaan farmasi milikswasta 2016-2018 dengan menggunaka menggunakan uji beda rata-rata dari variabel ROE, EPS, dan EVA. Dalam variabel ROE 
pada kinerja perusahaan farmasi milik BUMN terdapat perbedaan signifikan dalam persentase perusahaan BUMN berada diposisi tidak aman dan perusahaan milik Swasta ada diposisi aman karena berada diatas 15\%. Berdasarkan variabel EPS pada kinerja perusahaan farmasi milik BUMN dan perusahaan milik swasta apabila dilihat dari fundamental memiliki perbedaan untuk perusahaan farmasi milik BUMN hanya mencapai 0,35 saja, sedangkan untuk perusahaan farmasi milik swasta dapat mencapai 50,71. Serta dalam variabel EVA kinerja perusahaan farmasi milik BUMN selama tiga tahun ada perbedaan, sedangkan untuk perusahaan farmasi milik swasta selama tiga tahun terakhir kinerja keuangan mengalami penurunan yang signifikan.

Bagi manajemen perusahaan farmasi milik BUMN dan perusahaan farmasi milik swasta sebaiknya meningkatkan efisiensi dan efektivitas dalam memperoleh profit yang lebih maksimal dan optimal. Hal ini guna meningkatkan perkembangan dimana globalisasi sekarang semakin canggih dan berkembang pesat tiap tahunnya, sehingga perusahaan harus mampu bersaing dan berani dan memperoleh profit yang optimal dari masyarakat (investor) yakni dengan memberikan kepercayaan dan meningkatkan kulaitas produk, jasa pelayanan, distributor pada setiap perusahaannya.

\section{Daftar Pustaka}

Ahmad Tanzeh. 2009. Pengantar Metode Penelitian. Yogyakarta: Teras.

Kasmir. 2009. Pengantar Manajemen Kenangan. pertama. Jakarta.

M. Abdullah. 2014. Manajemen Dan Evaluasi Kinerja Karyawan. Yogyakarta: Aswaja Pressindo.

Doerachman, Darma, Parengkuan Tommy, and Paulina Van Rate. 2016.

"Perusahaan Farmasi Yang Terdaftar Di Bursa Efek Indonesia Periode 2011-2014." 16(03):27-37.

Dorotea Noesman Riberu. 2017. "Kinerja Keuangan Perusahaan dengan Menggunakan Rasio Keuangan dan Konsep Ekonomic Value Added (EVA) (Studi Kasus Pada PT. Pertamina Periode 2012-2014).” Ekonomi Akuntansi 2(1):22.

Enniyatul Mizan. 2018. "Pengaruh Pengukuran Return On Asset, Return On Equity, Earning Per Share, dan Ekonomic Value Added Terhadap Market Value Added." Akuntansi dan Investasi 3(1):28.

Galib, Mukhtar, Muhammad Hidayat. 2018. "Analisis Kinerja Perusahaan dengan Menggunakan Pendekatan Balanced Scorecard Pada PT. Bosowa Propertindo." Journal of Manajement and Buisiness 2(1):92-112.

Iwin Arnova. 2013. "Pengaruh Ukuran Kinerja ROA, ROE, EPS dan EVA Terhadap Return Saham" 2011, ." Ekonomi Bisnis 36-53.

Mardiyani, Mardiyani. 2017. "Analisis Perbandingan Kinerja Keuangan

Perusahaan Farmasi Milik Bumn Dan Swasta." Jurnal Inspirasi Bisnis Dan Manajemen 1(1):19.

Moerdiyanto. 2010. "Pengaruh Tingkat Pendidikan Manajer Terhadap Kinerja Perusahaan." Cakrawala Pendidikan 2-3.

Nurhidayah, Ronny Malavia Mardani, M. Agus Salim. n.d. "Analisis 
Perbandingan Kinerja Keuangan Antara Perusahaan Farmasi Milik Pemerintah (Bumn) Dengan Perusahaan Farmasi Milik Swasta Yang Terdaftar di Bursa Efek Indonesia (Bei) Periode Tahun 2014-2016." E - Jurnal Riset Manajemen PRODI MANAJEMEN 21-30.

Nurmila Dewi, Azizah Mardilla. 2016. "Pengaruh Kinerja Keuangan Terhadap Harga Saham Pada Emiten Yang Tergabung Dalam Jakarta Islamic Index" Jurnal Ekonomi Dan Bisnis 16(01).

Rahma Febriyanti. 2014. "Nalisis Pengaruh Return On Equity ( ROE ), Earning Per Share (EPS ), Dividend Per Share (DPS ) dan Economic Value Added ( EVA) Terhadap Market Value Added ( MVA) Pada Perusahaan Manufaktur Sektor Industri Barang Konsumsi Yang Terdapat Di Bursa Efek Indo.” Ekonomi Bisnis 1-28.

Ratih F D Simbolon, Moch. Dzulkiron, Muhammad Saifi. 2014. "Analisis Eva (Economic Value Added) Untuk Menilai Kinerja Keuangan Perusahaan (Studi Pada Perusahaan Farmasi Pada Bursa Efek Indonesia Periode 2010-2012)." Administrasi Bisnis (JAB) 8(1):1-8.

Ratu, Rifany Angelia. 2016. "Analisis Perbandingan Kinerja Keuangan Pada Pt . Kimia Farma Tbk , Dan Pt . Kalbe Farma Tbk Periode 2011-2014.” Jurnal Berkala Ilmiah Efisiensi 16(03):111-20.

Sampul, Gladys T. P., "Perbandingan Kinerja Keuangan Perusahaan Farmasi Milik Negara Dan Milik Swasta Yang Terdaftar Di Bursa Efek Indonesia." Jurnal EMBA 1(4):355-61.

Saragih, Fitriani. 2017. "Kinerja Keuangan Perusahaan Pada PT. Pelabuhan Indonesia I (Persero) Medan.” 57-68.

Yoga Prasetyo, Mulatsih., MM, Lasminiasih3. 2019. "Analisis Kinerja Keuangan Pt. Kalbe Farma, Tbk Menggunakan Economic Value Added Dan Market Value Added Sebagai Tolak Ukur Investor dalam Mengambil Keputusan.” (1):978-79. 
Perbandingan Kinerja Keuangan Perusahaan .... 